\title{
Onko puna-apilassa potentiaalia ?
}

\author{
Aila Vanhatalo ja Seija Jaakkola
}

Kotieläintieteen laitos, PL 28,00014 Helsingin yliopisto, etunimi.sukunimi@helsinki.fi

\section{Tiivistelmä}

Puna-apilalla on biologisen typensidontakykynsä ansiosta keskeinen rooli luomutuotannossa. Samasta syystä sen kiinnostavuus tavanomaisena viljelykasvina todennäköisesti lisääntyy tulevaisuudessa typpilannoitteiden kallistuessa energian hinnan nousun myötä. Puna-apilan viljelyvarmuutta pidetään kuitenkin tunnetusti heinäkasveja heikompana. Lisäksi puna-apilan käyttöön ruokinnassa voidaan tietyissä tapauksissa suhtautua varauksella mahdollisten haitallisten kasviestrogeenivaikutusten ja puhaltumisvaaran vuoksi. Puna-apilan erityisominaisuudet viljelyn, korjuun, säilönnän ja ruokintakäytön suhteen täytyykin ottaa huomioon pyrittäessä hyödyntämään puna-apilan positiivisia ominaisuuksia typpitalouden järjestämisessä.

Tässä kirjallisuuteen perustuvassa artikkelissa luodaan katsaus puna-apilan mahdollisuuksiin lypsylehmien karkearehuna. Kirjoituksessa käydään läpi keskeisiä puna-apilan säilöntään, ruokintaarvoon sekä puna-apilalla tuotetun maidon koostumukseen vaikuttavia tekijöitä. Tutkimus kuuluu MMM:n rahoittaman Luomututkimusohjelman projektiin "Puna-apila tehokkaasti luomumaidoksi".

Puna-apila poikkeaa monessa suhteessa sekä viljelykasvina että ruokinnallisilta ominaisuuksiltaan nurmiheinäkasveista. Koostumuksen erityispiirteistä johtuen puna-apila on myös vaikeammin säilöttävää materiaalia kuin heinäkasvit. Esikuivatuksen ja säilöntäaineen avulla säilöntä kuitenkin onnistuu. Tuoreen ja lievästi esikuivatun rehun säilönnässä on käytettävä happosäilöntäainetta virhekäymisen estämiseksi. Pidemmälle esikuivatun rehun säilönnässä myös biologisilla säilöntäaineilla saadaan hyvälaatuista rehua.

Seoksena heinäkasvien kanssa annettaessa puna-apila lisää säilörehun syöntiä sekä energiakorjatun maidon (EKM) ja valkuaisen tuotosta heinäkasvirehuihin verrattuna. Puhtaana syötettäessä punaapila ei välttämättä lisää säilörehun syöntiä, mutta lisää EKM- ja valkuaistuotosta huolimatta punaapilan maidon rasva- ja jossain määrin myös valkuaispitoisuuksia pienentävästä vaikutuksesta. Punaapila lisää monityydyttymättömien rasvahappojen (erityisesti linoleenihapon) pitoisuutta ja vähentää palmitiinihapon pitoisuutta maitorasvassa heinäkasviruokintoihin verrattuna.

Kun kokeissa käytetty väkirehutaso on ollut pieni $(<10 \mathrm{~kg} / \mathrm{pv})$, väkirehutason sekä täydennysvalkuaisen laadun ja tason vaikutus tuotosvasteisiin on yleensä ollut samanlainen riippumatta siitä onko perusrehuna ollut puna-apilaa sisältävä tai puhdas heinäkasvisäilörehu.

Puna-apilan käyttöä säilörehun raaka-aineena kannattaa lisätä nykyisestä. Tämä perustuu punaapilan hyviin maidontuotanto-ominaisuuksiin, sen suotuisaan vaikutukseen maidon rasvahappokoostumukseen sekä mahdollisuuteen säästää typpilannoituksen kustannuksissa. Puna-apilaa kannattaa käyttää ruokinnassa mieluimmin seoksena heinäkasvien kanssa kuin puhtaana. Tällöin muun muassa valkuaisen hyväksikäyttöä heikentävä tarpeettoman suuri ruokinnan raakavalkuaispitoisuus pienenee.

Asiasanat: puna-apila, maidontuotanto, säilöntäaineet 


\section{Johdanto}

Lypsylehmien ruokinta perustuu Suomessa yleisesti säilörehunurmeen, joka on tuotettu typpilannoitteilla ja joka säilötään happo- tai biologisilla säilöntäaineilla. Akateemikko A. I. Virtasella oli ratkaiseva rooli nurmirehun säilöntämenetelmän kehittämisessä. Säilöntähapon käytön lisäksi alkuperäiseen AIV-järjestelmään kuului oleellisena osana myös biologisen typensidonnan hyödyntäminen apilavaltaisia nurmia viljelemällä. Tavoitteena oli omavarainen typpitalous (Heikonen 1993). Nurmen korjuuja säilöntäteknologiassa 1960-70 luvuilla tapahtuneen ratkaisevan kehityksen ansiosta säilörehuun perustuva ruokintamalli tuli käytännössä vallitsevaksi noin 20-30 vuotta sitten. Virtasen alkuperäinen ajatus apilan hyödyntämisestä säilörehun tuotannossa jäi kuitenkin vähälle huomiolle, koska ns. vihreän linjan tutkimusten tuloksena heinänurmien sadontuotto mullistui voimaperäisen typpilannoituksen avulla. Typpilannoitteiden halpuuden vuoksi typpiomavaraisten kasvien kilpailukyky heikkeni ja apilan osuus nurmista pieneni vähiin.

Luonnonmukainen maidontuotanto perustuu palkokasvien typensidontakyvyn hyödyntämiseen ja karkearehun runsaaseen käyttöön lehmien ruokinnassa. Suomessa menestyvistä nurmipalkokasveista puna-apila todettiin tuottavuudeltaan edullisimmaksi säilörehukasviksi hiljattain valmistuneessa EU-rahoitteisessa Legsil-tutkimuksessa (Wilkins 2001). Puna-apilan painoarvo ja kiinnostavuus potentiaalisena säilörehun raaka-aineena on lisääntynyt viime vuosina myös tavanomaisessa maidontuotannossa. Tämä johtuu yleisesti lisääntyneistä kustannuspaineista EU-maiden maataloudessa ja erityisesti voimakkaasti nousevista fossiilisten polttoaineiden hinnoista. Biologisen typensidonnan hyödyntäminen lisäämällä puna-apilan käyttöä säilörehun raaka-aineena tarjoaa mahdollisuuden vähentää typpilannoituksen kustannuksia ja riippuvuutta fossiilisista polttoaineista. Legsil-tutkimuksessa arvioitiin, että jos puolet Pohjois-Euroopan heinäkasvinurmen tuotannosta korvattaisiin nurmipalkokasveilla syntyisi noin 700-1400 miljoonan euron vuotuiset säästöt (Wilkins 2001).

Puna-apilan potentiaalia lypsylehmien karkearehuna määrittävät sen viljelyyn, säilöntään ja ruokinnalliseen arvoon liittyvät ominaisuudet. Tässä kirjoituksessa keskitytään näistä kahteen jälkimmäiseen tekijään.

\section{Puna-apilan koostumus, korjuu ja säilöntä}

Puna-apilan tunnetuin ominaisuus on sen kyky sitoa ilmakehän typpeä juuriston bakteereiden avulla. Tämän erityispiirteen lisäksi myös puna-apilan rakenne, kemiallinen koostumus ja kehitysrytmi eroavat selvästi nurmiheinäkasveista. Nämä erot vaikuttavat edelleen kasvilajien säilöttävyyteen ja ruokinnalliseen arvoon.

Raakavalkuais-, ligniini-, INDF- (sulamaton kuitu) ja Ca-pitoisuus on tyypillisesti suurempi ja NDF-pitoisuus pienempi puna-apilassa kuin heinäkasveissa. Kotimaisissa ruokintatutkimuksissa eri kasvuasteilla tehtyjen puhtaiden puna-apilasäilörehujen raakavalkuaispitoisuus kuiva-aineessa (ka) on vaihdellut välillä 165 - $212 \mathrm{~g} / \mathrm{kg}$ ja NDF-pitoisuus välillä 348 - $492 \mathrm{~g} / \mathrm{kg}$ (taulukko 1). Huolimatta suuremmasta ligniini- ja INDF-pitoisuudesta puna-apilan ja heinäkasvien orgaanisen aineen sulavuus on rehutaulukossa suunnilleen sama säilörehun korjuuasteilla. Sen sijaan puna-apilan D-arvo on suuremmasta tuhkapitoisuudesta johtuen pienempi kuin heinäkasvien (MTT Rehutaulukot ja ruokintasuositukset 2005). Puhtaan heinäkasvinurmen optimaalisen korjuuajankohdan arvioimista varten annettu D-arvosuositus ei sellaisenaan käykään puhtaalle puna-apilakasvustolle. Van Soestin (1994) mukaan palkokasvien ligniinipitoisuus on noin kaksinkertainen heinäkasveihin verrattuna silloin, kun näiden kasvien sulavuudet ovat samat. Kasvilajien erilaiseen kuiturakenteeseen liittyy erilainen sulatus- ja virtauskinetiikka ruoansulatuskanavassa (Kuoppala ym. 2006). Rinteen (2000) mukaan punaapilan sulavuuden heikkeneminen kasvin kehityksen myötä kesän ensikasvussa on tutkimuksissa ollut keskimäärin puolet hitaampaa kuin nurmiheinäkasvien (D-arvon muutos 2,5 vs 5,0 g/kg ka/pv).

Kasvin ominaisuudet, säilöntätekniikka ja sääolosuhteet vaikuttavat rehun säilönnän onnistumiseen. Puna-apilan säilöntä on muiden nurmipalkokasvien tavoin haastavampaa kuin nurmiheinäkasvien säilöntä. Syynä on apilan suurempi puskurikapasiteetti, pienempi sokeripitoisuus ja pienempi kuiva-ainepitoisuus heinäkasveihin verrattuna (McDonald ym. 1991). Nämä tekijät vaikeuttavat säilöntää ja lisäävät virhekäymisen riskiä. Apilan säilönnässä on erityisen tärkeää parantaa säilönnän onnistumisen mahdollisuuksia säilöntäaineen ja esikuivatuksen avulla.

Orgaaniset hapot ovat tärkein syy palkokasvien korkeaan puskurikapasiteettiin eli kykyyn vastustaa pH:n laskua säilörehussa. Syrjälä-Qvistin ym. (1984) kokeessa puna-apilan kasvihappopitoisuus 
Taulukko 1. Puna-apilapitoisten ja puhtaiden puna-apilasäilörehujen säilönnällinen laatu lypsylehmien ruokintatutkimuksissa. Koostumustiedoissa ammonium typpi ja liukoinen typpi, g/kg N, muut g/kg ka.

\begin{tabular}{|c|c|c|c|c|c|c|c|c|c|c|c|c|}
\hline Lähde & $\begin{array}{c}\text { Apila } \\
\%\end{array}$ & Säilö & $\begin{array}{l}\text { Saine } \\
\text { /annos }\end{array}$ & $\begin{array}{l}\mathrm{Ka}, \\
\mathrm{g} / \mathrm{kg}\end{array}$ & $\begin{array}{l}\text { Raaka } \\
\text { valk. }\end{array}$ & NDF & $\mathrm{pH}$ & Sokeri & $\begin{array}{l}\text { Maito- } \\
\text { happo }\end{array}$ & $\begin{array}{c}\text { Voi- } \\
\text { happo }\end{array}$ & $\begin{array}{l}\text { Amm. } \\
\text { typpi }\end{array}$ & $\begin{array}{l}\text { Liuk. } \\
\text { typpi }\end{array}$ \\
\hline \multicolumn{13}{|c|}{ Thomas ym. 1985} \\
\hline & 100 & & $\mathrm{H}+\mathrm{F}$ & 226 & 180 & 493 & 4,20 & & 49 & 2,3 & 79 & \\
\hline \multicolumn{13}{|c|}{ Vanhatalo ym. 1995} \\
\hline & 40 & $\mathrm{~T}$ & H 5,6 & 240 & 159 & 483 & 4,20 & 94 & 16 & 0,0 & 32 & 439 \\
\hline \multicolumn{13}{|c|}{ Heikkilä ym. 1996} \\
\hline Koe 1 & 30 & $\mathrm{~T}$ & H 5-6 & 289 & 156 & 495 & 4,14 & 64 & 48 & 0,0 & 37 & 517 \\
\hline Koe 2 ja 3 & 70 & tai & H 5-6 & 244 & 155 & 493 & 4,25 & 62 & 44 & 3,1 & 50 & 363 \\
\hline Koe 4 & 60 & LS & & 242 & 147 & 512 & 4,01 & 50 & 43 & 1,8 & 36 & 326 \\
\hline \multicolumn{13}{|c|}{ Tuori ym. 2000} \\
\hline \multicolumn{13}{|l|}{ Tuori ym. 2002} \\
\hline & 100 & $\mathrm{P}$ & H 6 & 390 & 201 & 386 & 4,61 & 51 & 65 & 0,2 & 91 & 459 \\
\hline \multicolumn{13}{|c|}{ Dewhurst ym. 2003} \\
\hline Koe 1 & 100 & $\mathrm{P}$ & B & 376 & 196 & 419 & 4,24 & 18 & 74 & 5,1 & 104 & \\
\hline Koe 2 & 100 & $\mathrm{P}$ & B & 231 & 181 & 407 & 4,38 & 7 & 84 & 9,7 & 129 & \\
\hline \multicolumn{13}{|c|}{ Bertilson ja Murphy 2003} \\
\hline Koe 1 & 100 & $\mathrm{P}$ & Muu & 263 & 205 & 353 & 5,10 & 5 & 68 & 1,0 & 113 & \\
\hline Koe 2 & 100 & $\mathrm{P}$ & Muu & 306 & 196 & 329 & 4,4 & 35 & 79 & 0,1 & 65 & \\
\hline \multicolumn{13}{|c|}{ Pursiainen ym. 2006} \\
\hline & 100 & $\mathrm{P}$ & H 5 & 180 & 166 & 395 & 4,05 & 3 & 102 & 0,1 & 62 & 360 \\
\hline & 100 & $\mathrm{P}$ & H 5 & 224 & 165 & 391 & 4,30 & 12 & 106 & 0,5 & 112 & 470 \\
\hline & 100 & $\mathrm{P}$ & H 5 & 251 & 170 & 373 & 4,22 & 33 & 86 & 0,1 & 68 & 372 \\
\hline & 100 & $\mathrm{P}$ & H 5 & 219 & 193 & 348 & 4,31 & 8 & 98 & 0,1 & 66 & 389 \\
\hline \multicolumn{13}{|c|}{ Kuoppala ym. 2006 ja Vanhatalo ym. 2006} \\
\hline & 100 & A & H 6 & 214 & 212 & 375 & 4,15 & 17 & 50 & 0,3 & 25 & 277 \\
\hline & 100 & A & H 6 & 212 & 181 & 463 & 4,10 & 20 & 38 & 0,5 & 32 & 288 \\
\hline & 100 & A & H 6,5 & \multicolumn{3}{|c|}{ Rinne ym. 2006} & 3,79 & 94 & 16 & 0,3 & 48 & 297 \\
\hline
\end{tabular}

T=torni, LS=laakasiilo, A=auma, $\mathrm{P}=$ paali; Säilöntäaineen annostus 1/t, H=happo, $\mathrm{F}=$ formaldehydi, $\mathrm{B}=$ biologinen säilöntäaine

oli 67 ja timotein $35 \mathrm{~g} / \mathrm{kg}$ ka. Myös puna-apilan suuri valkuaispitoisuus lisää puskuroivaa vaikutusta. Huolimatta puna-apilan suuremmasta solunsisällysaineiden määrästä apilan keskimääräinen sokeripitoisuus on pienempi kuin nurmiheinäkasvien. Sokeripitoisuuden ero meillä eniten viljeltyihin heinäkasveihin (timotei, nurminata) ei kuitenkaan ole yhtä suuri kuin raiheinään verrattuna. Fruktaanit ovat nurmiheinäkasvien tärkein varastopolysakkaridi. Palkokasveissa vastaava varasto on tärkkelys, joka ei ole vesiliukoinen eikä se ole muutenkaan helposti maitohappobakteereiden käytössä rehun luontaisessa käymisessä (McDonald ym. 1991).

Esikuivatus vähentää virhekäymisen riskiä apilan säilönnässä, mutta apilan rakenteelliset ominaisuudet vaikeuttavat kuivatusprosessia. Puna-apilan vahva korsi hidastaa kuivumista. Kuivumisen olisi oltava mahdollisimman nopeaa, sillä hengitystappiot ovat sitä suuremmat mitä pidempään ja huonommassa säässä kuivatus tapahtuu. Toisaalta puna-apilan lehdet kuivuvat nopeasti, mutta ovat samalla herkkiä varisemaan. Esikuivatus korkeaan kuiva-ainepitoisuuteen ja voimakas käsittely aiheuttavat helposti korjuutappioita.

Edellä mainittujen puna-apilan ominaisuuksien merkitys säilörehussa painottuu sen mukaan mikä on puna-apilan osuus viljellyssä seoksessa. Apilavaltainen seosviljely saattaa tosin osittain muuttaa heinäkasvin säilönnällisiä ominaisuuksia puhtaaseen heinäkasvinurmeen verrattuna, jos nurmelle ei anneta typpilannoitusta. Typpilannoitus vaikuttaa heinäkasvien säilöttävyyteen kahdella tavalla (Jaakkola ym. 2000). Lannoitus pienentää kasvin kuiva-aine- ja sokeripitoisuutta, mikä vaikeuttaa säilöntää. Toisaalta typpilannoitus lisää rehun nitraattipitoisuutta, joka edistää säilymistä estämällä voihappokäymistä. Heinäkasvin sulavuuden heikkeneminen lannoittamattomassa luomunurmessa on kuitenkin yhtä nopeaa kuin tavanomaisessa heinäkasvustossa (Rinne 2000). 
Apilapitoisten säilörehujen ja puhtaiden apilarehujen säilönnällinen laatu on ollut pääosin hyvä, kun kuiva-ainepitoisuus on ollut $150-400 \mathrm{~g} / \mathrm{kg}$ ja happopohjaista säilöntäainetta on käytetty $5-6,5 \mathrm{l} / \mathrm{t}$ kotimaisissa säilöntäkokeissa (Syrjälä-Qvist ym. 1984, Syrjälä-Qvist ym. 1985) ja ruokintakokeissa (taulukko 1). Vain muutamissa koerehuissa on ollut suhteellisen korkea voihappopitoisuus (Heikkilä ym. 1996) tai korkea ammoniumtypen osuus (Pursiainen ym. 2006). Laboratoriomittakaavan kokeen perusteella runsas happoannostus (6/t) on ainoa varma tapa säilöä nuorella nuppuasteella tuoretta tai lievästi esikuivattua $(250 \mathrm{~g} / \mathrm{kg}$ ) puna-apilaa (Tuori ym. 2000). Sen sijaan kukintavaiheessa tehty lievästi esikuivattu puna-apilarehu $(250 \mathrm{~g} / \mathrm{kg})$ säilyi hyvin myös biologisia säilöntäaineita käytettäessä. Vastaavasti englantilaisessa tutkimuksessa paalirehun $\mathrm{pH}$ oli korkea, voihappoa oli runsaasti ja ammoniumtypen osuus oli suuri, kun lievästi esikuivattu puna-apila säilöttiin biologisella säilöntäaineella (Dewhurst ym. 2003). Kyseisessä tutkimuksessa myös enemmän esikuivatun säilörehun (kuivaainepitoisuus $376 \mathrm{~g} / \mathrm{kg}$ ) voihapon pitoisuus ja ammoniumtypen osuus olivat suuria.

Puna-apilan valkuainen hajoaa säilönnän aikana vähemmän kuin sinimailasen ja heinäkasvien valkuainen (esim. Syrjälä-Qvist ym. 1984). Tämä näkyy suhteellisen pienenä liukoisen typen osuutena säilörehussa (taulukko 1). Ammoniumtypen osuus apilarehuissa ei sen sijaan ole yhtä selkeästi poikennut tyypillisestä hapolla säilötystä heinäkasvisäilörehusta. Rajoittunut proteolyysi on yhteydessä polyfenolioksidaasi-entsyymin (PPO) ja o-difenolin esiintymiseen kasvissa. PPO saa aikaan myös niitetylle apilalle tyypillisen ruskean värin. Ruskea väri rikkoutuneessa kasvinosassa vaikuttaa negatiivisesti esimerkiksi hedelmien laatuun. Sen sijaan puna-apilassa värireaktio indikoi positiivista vaikutusta valkuaisen hajoamisen vähentyessä säilönnän aikana. PPO katalysoi ilmeisesti fenolin muuttumista toiseksi yhdisteeksi (o-quinone), joka puolestaan sitoutuu ja samalla inaktivoi endogeenisia proteaaseja (Jones ym. 1995, Sullivan ym. 2004).

Puna-apilassa on myös muita ruokinnassa huomioon otettavia erityispiirteitä, joita tässä kirjoituksessa ei käsitellä tarkemmin. Puna-apilan kivennäiskoostumus poikkeaa nurmiheinäkasveista. Selkein ero on Ca-pitoisuudessa, joka on puna-apilassa 3-5-kertainen nurmiheinäkasveihin verrattuna. Puna-apila sisältää myös estrogeenisia aineita, jotka eivät häviä säilönnän aikana. Hyvin runsas kasviestrogeenien saanti voi vaikuttaa negatiivisesti lähinnä lampaiden hedelmällisyyteen (Mustonen ym. 2006). Lisäksi puna-apilassa on puhaltumista aiheuttavia aineita, joiden vaikutus heikkenee kuitenkin selvästi säilörehun valmistuksessa.

\section{Puna-apilan syönti ja tuotantovaikutus}

Yleensä puna-apilaa viljellään seoksena heinäkasvien kanssa, joten säilörehun apilapitoisuus vaihtelee. Koska vertailtavien kasvilajien kasvuaste ja säilönnällinen laatu ovat monissa tutkimuksissa myös vaihdelleet yksiselitteistä kuvaa puna-apilan vaikutuksesta säilörehun syöntiin ja tuotosvasteisiin on vaikea saada. Toisin kuin heinäkasvirehujen (Rinne 2000) puna-apilan kasvuasteen tuotantovaikutuksia ei ole juuri tutkittu lukuun ottamatta uusimpia kotimaisia tutkimuksia. Puhtaaseen heinäkasvisäilörehuun verrattuna puna-apilan syöttäminen seoksena heinäkasvisäilörehun kanssa on yleensä lisännyt sekä säilörehun syöntiä että maitotuotosta. Kirjallisuuden perusteella tehdyn yhteenvedon (taulukko 2; 13 vertailua) mukaan säilörehun kuiva-aineen syönti lisääntyi keskimäärin $1,3 \mathrm{~kg} / \mathrm{pv}$ (vaihteluväli $0,0-$ $2,5 \mathrm{~kg} / \mathrm{pv}$ ) ja maitotuotos $1,4 \mathrm{~kg} / \mathrm{pv}$ (vaihteluväli -0,2-2,8) puna-apilan osuuden säilörehusta vaihdellessa välillä 30-70\%. Apilapitoinen rehu pienensi hieman sekä maidon rasva- $(-1,5 \mathrm{~g} / \mathrm{kg})$ että valkuaispitoisuuksia $(-0,4 \mathrm{~g} / \mathrm{kg})$ heinäkasvirehuun verrattuna, jolloin keskimääräinen energiakorjatun maidon (EKM) tuotoksen lisäys jäi maitotuotoksen lisäystä pienemmäksi (0,9 vs. 1,4 kg/pv). Vertailtavien ruokintojen keskimääräinen sulavuus oli sama (vaihteluväli -0,030-0,035).

Osassa tutkimuksista puna-apilaa on verrattu heinäkasvirehuihin myös käyttäen puhtaasta punaapilakasvustosta tehtyä rehua. Tällöin puhtaan puna-apilan vaikutukset erityisesti säilörehun syöntiin ovat olleet hyvin vaihtelevia. Tehdyn yhteenvedon (taulukko 3; 12 vertailua) mukaan puhtaan punaapilan keskimääräisessä syönnissä ei ollut juuri eroa heinäkasvirehuihin verrattuna $(+0,3 \mathrm{~kg} / \mathrm{pv})$, mutta syönti vaihteli suuresti kokeesta riippuen. Joissakin kokeissa lehmät söivät puna-apilasäilörehua huomattavasti vähemmän kuin heinäkasvirehua ja joissakin enemmän (vaihteluväli -3,6-2,6 kg/pv). Myös vertailtavien ruokintojen orgaanisen aineen sulavuudet vaihtelivat suuresti $(-0,071-0,113)$. Vaihtelevasta syönnistä huolimatta puna-apila nosti maitotuotosta heinäkasvirehuihin verrattuna keskimäärin enemmän kuin puna-apilapitoinen säilörehu ( 1,7 vs. $1,4 \mathrm{~kg} / \mathrm{pv})$. Puhdasta puna-apilaa syötettäessä maidon rasva- $(-1,8 \mathrm{~g} / \mathrm{kg})$ ja valkuaispitoisuudet $(-1,2 \mathrm{~g} / \mathrm{kg})$ pienenivät voimakkaammin kuin puna- 
Taulukko 2. Puna-apilapitoisen säilörehun vaikutus säilörehun kuiva-aineen syöntiin, maitotuotokseen, maidon rasva- ja valkuaispitoisuuksiin sekä ruokinnan orgaanisen aineen sulavuuteen yksinomaiseen heinäkasvisäilörehuruokintaan verrattuna

\begin{tabular}{|c|c|c|c|c|c|c|c|}
\hline Lähde & $\begin{array}{l}\text { Säilörehun } \\
\text { syönti } \\
\mathrm{kg} \mathrm{ka} / \mathrm{pv}\end{array}$ & $\begin{array}{l}\text { Maito- } \\
\text { tuotos } \\
\mathrm{kg} / \mathrm{pv}\end{array}$ & $\begin{array}{l}\text { EKM- } \\
\text { tuotos } \\
\mathrm{kg} / \mathrm{pv}\end{array}$ & $\begin{array}{l}\text { Rasva } \\
\mathrm{g} / \mathrm{kg}\end{array}$ & $\begin{array}{l}\text { Valku- } \\
\text { ainen } \\
\text { g/kg }\end{array}$ & $\begin{array}{c}\text { Valkuais- } \\
\text { tuotos } \\
\mathrm{g} / \mathrm{pv}\end{array}$ & $\begin{array}{c}\text { Ruokinnan } \\
\text { sulavuus } \\
\text { g/g }\end{array}$ \\
\hline \multicolumn{8}{|l|}{ Heikkilä ym. 1996} \\
\hline Koe $1(0,30)^{*}$ & $+1,7$ & $+1,6$ & $+1,0$ & $-2,1$ & $+0,1$ & +58 & 0,000 \\
\hline Koe $2(0,70)$ & $+0,0$ & $+1,1$ & $+0,1$ & $-2,4$ & $-1,4$ & -2 & $-0,030$ \\
\hline Koe $3(0,70)$ & $+0,3$ & $-0,2$ & $-0,3$ & $-0,5$ & $+0,5$ & +7 & $-0,030$ \\
\hline Koe $4(0,60)$ & $+2,5$ & $+3,8$ & $+3,9$ & $+0,5$ & $-0,5$ & +103 & $-0,010$ \\
\hline Tuori ym, 2000 & $+0,8$ & $+1,3$ & $+0,8$ & $-0,7$ & $-0,4$ & +25 & \\
\hline \multicolumn{8}{|l|}{ Tuori ym, 2002} \\
\hline Vertailu 1 (0.33) & $+2,3$ & 0,0 & 0,0 & $-0,1$ & $-0,1$ & -3 & $-0,010$ \\
\hline Vertailu 2 (0.67) & $+1,6$ & $+0,5$ & $-1,0$ & $-4,1$ & $+0,2$ & +19 & $+0,016$ \\
\hline \multicolumn{8}{|l|}{ Dewhurst ym. 2003} \\
\hline Koe 1 & $+1,5$ & $+3,7$ & $+4,5$ & $+1,5$ & $-0,5$ & +113 & -0.033 \\
\hline Koe 2, vertailu 1 & $+0,5$ & $+0,2$ & $+0,2$ & $-0,6$ & 0,0 & +19 & $+0,035$ \\
\hline Koe 2, vertailu 2 & $+0,9$ & $+1,1$ & $+0,2$ & $-3,1$ & $-0,3$ & +55 & $-0,017$ \\
\hline \multicolumn{8}{|c|}{ Bertilsson ja Murphy 2003} \\
\hline Koe 1 & $+1,9$ & $+1,6$ & $+0,6$ & $-3,2$ & $-0,5$ & +40 & $+0,027$ \\
\hline Koe 2 & $+0,8$ & $+1,3$ & $+0,6$ & $-2,0$ & $-1,2$ & +10 & $+0,018$ \\
\hline Vanhatalo ym, 2006 & $+2,0$ & $+2,2$ & $+1,2$ & $-2,6$ & $-1,1$ & +41 & $+0,019$ \\
\hline Keskiarvo & $+1,3$ & $+1,4$ & $+0,9$ & $-1,5$ & $-0,4$ & +38 & $-0,001$ \\
\hline Vaihteluväli & $+0,0-2,5$ & $-0,2-3,8$ & $-1,0-4,5$ & $-4,1-1,5$ & $-1,4-0,5$ & $-3,0-103$ & $-0,030-0,035$ \\
\hline
\end{tabular}

*Puna-apilan osuus seoksessa; muissa kokeissa puna-apilaa ja heinäkasvia oli suhteessa 1:1.

apilapitoista rehua syötettäessä. Tästä johtuen EKM-tuotoksen lisäys heinäkasvirehuihin verrattuna oli kuitenkin puhtaalla puna-apilalla $(0,8 \mathrm{~kg} / \mathrm{pv}$; vaihteluväli $-2,0-4,0 \mathrm{~kg} / \mathrm{pv})$ lähes sama kuin puna-apilapitoisella rehulla.

\section{Puna-apilan täydennysruokinnan vaikutus}

Kirjallisuudessa on niukasti tutkimuksia, joissa on selvitetty onko puna-apila- tai heinäkasvi-säilörehuun perustuvan ruokinnan täydennystarpeessa eroja. Puna-apilaruokinta lisäsi lypsylehmien aminohappojen saantia heinäkasviruokintaan verrattuna (Vanhatalo ym. 2006), mutta edellä esitetyn yhteenvedon (taulukot 2 ja 3) mukaan maidon valkuaispitoisuus on keskimäärin pienentynyt puna-apilaa annettaessa. Suuremmasta maitotuotoksesta johtuen puna-apilaruokinta kuitenkin lisäsi keskimäärin valkuaistuotosta $38 \mathrm{~g} / \mathrm{pv}$ vaihteluvälin ollessa $+3-103$ (taulukko 2) tai $20 \mathrm{~g} / \mathrm{pv}$ vaihteluvälin ollessa $70-75 \mathrm{~g} / \mathrm{pv}$ (taulukko 3).

Heikkilän (2002) kokeessa väkirehun valkuaismäärän lisääminen (rypsirouhetta $10 \%$ vs. $20 \%$ ) vaikutti samalla tavalla maito- ja valkuaistuotosta lisäävästi sekä nurminata-timotei- että puna-apilapitoista $(60 \%)$ säilörehua sisältävillä ruokinnoilla. Rypsi- ja hernetäydennyksillä saadut tuotosvasteet olivat likimain samanlaisia riippumatta siitä oliko perusrehuna nurminata-timotei- tai puna-apilapitoinen (70 \%) säilörehu (Heikkilä ja Toivonen 1997). Samoin kaura lisäsi ohraan verrattuna maitotuotosta, mutta pienensi maidon valkuaispitoisuutta sekä nurminata-timotei- että apilapitoista (40\%) säilörehua syötettäessä (Vanhatalo ym. 1995).

Rinteen ym. (2006) kokeessa käytettäessä perusrehuna puna-apilan ja heinäkasvirehun seosta (1:1) lehmät lisäsivät säilörehun syöntiä ja tuottivat maitoa ja valkuaista enemmän rypsi- kuin soijapuristeella. Todetut tuotosvasteet olivat samaa tasoa kuin aikaisemmissa heinäkasvirehuilla tehdyissä kokeissa. Joissakin kokeissa käytettäessä puna-apilapitoista säilörehua valkuaisrehuilla saadut tuotosvasteet ovat olleet pienempiä kuin yleensä heinäkasviruokinnoilla. Esimerkiksi Khalilin ym. (1999) kokeessa valkuaisrehut eivät lisänneet säilörehun syöntiä, mutta nostivat maito- ja valkuaistuotoksia, 
Taulukko 3. Puhtaasta puna-apilakasvustosta tehdyn säilörehun vaikutus säilörehun kuiva-aineen syöntiin, maitotuotokseen, maidon rasva- ja valkuaispitoisuuksiin sekä ruokinnan orgaanisen aineen sulavuuteen yksinomaiseen heinäkasvisäilörehuruokintaan verrattuna

\begin{tabular}{lccccccc}
\hline Lähde & $\begin{array}{c}\text { Säilörehun } \\
\text { syönti } \\
\mathrm{kg} \mathrm{ka} / \mathrm{pv}\end{array}$ & $\begin{array}{c}\text { Maito- } \\
\text { tuotos } \\
\mathrm{kg} / \mathrm{pv}\end{array}$ & $\begin{array}{c}\text { EKM- } \\
\text { tuotos } \\
\mathrm{kg} / \mathrm{pv}\end{array}$ & $\begin{array}{c}\text { Rasva } \\
\mathrm{g} / \mathrm{kg}\end{array}$ & $\begin{array}{c}\text { Valku- } \\
\text { ainen } \\
\mathrm{g} / \mathrm{kg}\end{array}$ & $\begin{array}{c}\text { Valkuais- } \\
\text { tuotos } \\
\mathrm{g} / \mathrm{pv}\end{array}$ & $\begin{array}{c}\text { Ruokinnan } \\
\text { sulavuus } \\
\mathrm{g} / \mathrm{g}\end{array}$ \\
\hline Thomas ym. 1985 & $+1,8$ & $+1,9$ & $+0,5$ & $-4,0$ & $-0,5$ & +39 & $-0,023$ \\
Tuori ym. 2000 & $+0,5$ & $+1,2$ & $+0,4$ & $-1,4$ & $-0,4$ & +20 & \\
Tuori ym. 2002 & $-0,5$ & $+2,0$ & $+0,7$ & $-3,3$ & $-0,6$ & +40 & $+0,044$ \\
Dewhurst ym. 2003 & & & & & & & \\
$\quad$ Koe 1 & $+2,0$ & $+3,2$ & $+4,0$ & $+0,7$ & $-1,2$ & +75 & $-0,071$ \\
$\quad$ Koe 2, vertailu 1 & $+2,6$ & $+2,1$ & $+2,7$ & $+1,8$ & $-0,4$ & +53 & $+0,014$ \\
$\quad$ Koe 2, vertailu 2 & $+2,6$ & $+2,7$ & $+1,2$ & $-3,6$ & $-1,7$ & +62 & $-0,006$ \\
Bertilsson ja Murphy 2003 & & & & & & & \\
$\quad$ Koe 1 & $+0,9$ & $+2,3$ & $+1,6$ & $-1,7$ & $-0,5$ & +60 & $-0,005$ \\
$\quad$ Koe 2 & $-2,2$ & $-0,4$ & $-2,0$ & $-2,5$ & $-2,2$ & -70 & $+0,004$ \\
$\quad$ Vanhatalo ym. 2006 & & & & & & & \\
$\quad$ Vertailu 1 & $-1,9$ & $+0,6$ & $-1,3$ & $-3,5$ & $-2,2$ & -59 & $+0,012$ \\
$\quad$ Vertailu 2 & $+0,1$ & $+1,8$ & $+0,8$ & $-1,8$ & $-1,8$ & +4 & $+0,004$ \\
Pursiainen ym. 2006 & & & & & & & \\
$\quad$ Vertailu 1 & $-3,6$ & $-0,3$ & $-0,7$ & $+0,3$ & $-1,5$ & -52 & $+0,086$ \\
$\quad$ Vertailu 2 & $+0,7$ & $+2,9$ & $+2,0$ & $-3,1$ & $-1,0$ & +72 & $+0,113$ \\
Keskiarvo & $\mathbf{+ 0 , 3}$ & $\mathbf{+ 1 , 7}$ & $\mathbf{+ 0 , 8}$ & $\mathbf{- 1 , 8}$ & $\mathbf{- 1 , 2}$ & $\mathbf{+ 2 0}$ & $\mathbf{+ 0 , 0 1 6}$ \\
Vaihteluväli & $-3,6-2,6$ & $-0,4-3,2$ & $-2,0-4,0$ & $-3,6-0,7$ & $-2,2-04$ & $-70-75$ & $-0,071-0,113$ \\
\hline
\end{tabular}

kun perusrehuna oli puna-apilapitoinen (40 \%) säilörehu. Kokeessa verratut herne ja rypsirehut osoittautuivat samanarvoisiksi valkuaislähteiksi. Toisessa vastaavassa vertailussa rypsitäydennys sen sijaan lisäsi säilörehun syöntiä sekä maito- ja valkuaistuotoksia, ja rypsin korvaaminen herneellä heikensi tuotosvasteita (Khalili ym. 2002).

Väkirehutason nostaminen (4 vs. $8 \mathrm{~kg} / \mathrm{pv}$ ) vähensi säilörehun syöntiä, mutta lisäsi maito- ja valkuaistuotoksia samalla tavalla riippumatta siitä oliko perusrehuna puna-apila- tai raiheinäsäilörehu (Dewhurst ym. 2003).

\section{Puna-apilan vaikutus maidon koostumukseen}

Puna-apilaruokinta on usein pienentänyt maidon rasvapitoisuutta ja jossain määrin myös valkuaispitoisuutta. Toisaalta se on aiheuttanut suotuisia muutoksia maidon rasvahappokoostumukseena. Kerta- ja moni-tyydyttymättömien (mm. linoli- ja linoleenihappo) rasvahappojen osuuden lisäämisen ravinnossa vaikuttaa terveydelle suotuisasti ihmisen veren rasva-arvoihin (Scollan ym. 2005). Puna-apila on lisännyt maidon monityydyttymättömien rasvahappojen ja varsinkin $\alpha$-linoleenihapon pitoisuuksia nurminata- (Tuori ym. 2004) ja raiheinäsäilörehuun (Dewhurstin ym. 2003) verrattuna. Viimeksi mainitussa kokeessa apilarehu lisäsi myös jonkin verran maidon konjugoidun linolihapon pitoisuutta ja pienensi palmitiinihapon osuutta maitorasvassa. Myös Vanhatalon ym. (2006) ja Pursiaisen ym. (2006) kokeissa (julkaisemattomat tulokset) puna-apilaruokinnat vaikuttivat maidon rasvahappokoostumukseen samalla tavalla. Jälkimmäisessä kokeessa maidon linoleenihapon pitoisuus oli suurempi ensisadon apila- kuin heinäkasviruokinnoilla. Lisäksi linoleenihappopitoisuus oli edelleen suurempi apilan 2. kuin 1. sadossa. Myös Heikkilän ym. (1996) kokeissa puna-apilapitoisella rehulla tuotettu maitorasva oli jodiluvun perusteella arvioituna pehmeämpää kuin heinäkasvirehulla tuotettu.

Scollan'in ym. (2005) mukaan puna-apilan ja heinäkasvin linoleenihappopitoisuuksissa ei ole eroja, mutta linoleenihappo biohydrogenoituu pötsissä vähemmän puna-apilaan kuin heinäkasviin perustuvilla ruokinnoilla. Tämän arveltiin johtuvan puna-apilan sisältämästä polyfenolioksidaasista, joka vähentää lipolyysiä pötsissä. 


\section{Yhteenveto ja johtopäätökset}

Puna-apila poikkeaa heinäkasveista sekä koostumuksen että rakenteen puolesta. Koostumuksesta johtuen puna-apila on vaikeammin säilöttävää materiaalia kuin heinäkasvit. Esikuivatuksen ja säilöntäaineen avulla puna-apilan säilöntä kuitenkin onnistuu. Tuoreen ja lievästi esikuivatun rehun säilönnässä on käytettävä happosäilöntäainetta virhekäymisen estämiseksi. Pidemmälle esikuivatun rehun säilönnässä myös biologisilla säilöntäaineilla saadaan hyvälaatuista rehua.

Seoksena heinäkasvien kanssa annettaessa puna-apila lisää säilörehun syöntiä sekä EKM- ja valkuaistuotosta heinäkasvirehuihin verrattuna. Puhtaana syötettäessä puna-apila ei välttämättä lisää säilörehun syöntiä, mutta lisää EKM- ja valkuaistuotosta huolimatta puna-apilan maidon rasva- ja jossain määrin myös valkuaispitoisuuksia pienentävästä vaikutuksesta. Puna-apila lisää monityydyttymättömien rasvahappojen (erityisesti linoleenihapon) pitoisuutta ja vähentää palmitiinihapon pitoisuutta maitorasvassa heinäkasviruokintoihin verrattuna.

Kun kokeissa käytetty väkirehutaso on ollut pieni $(<10 \mathrm{~kg} / \mathrm{pv})$, väkirehutason ja täydennysvalkuaisen laadun sekä tason vaikutus tuotosvasteisiin on yleensä ollut samanlainen riippumatta siitä onko perusrehuna ollut puna-apilaa sisältävä tai puhdas heinäkasvisäilörehu.

Puna-apilan käyttöä säilörehun raaka-aineena kannattaa lisätä nykyisestä. Tämä perustuu punaapilan hyviin maidontuotanto-ominaisuuksiin, sen suotuisaan vaikutukseen maidon rasvahappokoostumukseen sekä mahdollisuuteen säästää typpilannoituksen kustannuksissa. Puna-apilaa kannattaa käyttää ruokinnassa mieluimmin seoksena heinäkasvien kanssa kuin puhtaana. Tällöin muun muassa valkuaisen hyväksikäyttöä heikentävä tarpeettoman suuri ruokinnan raakavalkuaispitoisuus pienenee.

\section{Kirjallisuus}

Bertilsson, J., Murphy, M. 2003. Effects of feeding clover silages on feed intake, milk production and digestion in dairy cows. Grass Forage Sci. 58: 309-322.

Dewhurst, R. J., Fisher, W.J., Tweed, J.K.S., Wilkins R. J. 2003. Comparison of grass and legume silages for milk production. 1. Production response with different levels of concentrate. J. Dairy Sci. 86: 2598-2611.

Heikkilä, T. 2002. Yksivuotinen raiheinäsäilörehu maidontuotannossa. In: Maataloustieteen Päivät 2002: Kotieläintiede, 9.-10.1.2002 Viikki, Helsinki. Maaseutukeskusten Liiton julkaisuja 977: p. 147-150.

Heikkilä, T., Toivonen, V., Mela, T. 1996. Puna-apilapitoinen säilörehu parantaa maitotuotosta. Koetoiminta ja käytäntö 24.1.1996 s.2.

Heikkilä, T., Toivonen, V. 1997. Herne ja rypsirouhe lehmien valkuaisrehuna säilörehuruokinnalla. In: Kotieläintieteen päivät 1997. Maaseutukeskusten Liiton julkaisuja 914: 187-190.

Heikonen, M. 1993. AIV Isänmaan aika. Karisto Oy:n kirjapaino, Hämeenlinna. 332 p.

Jaakkola S., Toivonen, V., Huhtanen, P. 2000. Typpilannoituksen ja säilöntäaineen vaikutus nurmisäilörehun laatuun. In: Maataloustieteen päivät 2000: kotieläintiede. Maaseutukeskusten Liiton julkaisuja 952. p. 118-121.

Jones, B. A., Hatfield, R. D., Muck, R. E. 1995. Screening legume forages for soluble phenols, polyfenol oxidase and extract browning. J. Sci. Food Agric. 67: 109-112.

Khalili, H., Kuusela, E., Saarisalo, E., Suvitie, M. 1999. Use of rapeseed and pea grain protein supplements for organic milk production. Agricultural and food science in Finland 8, 3: 239-252.

Khalili, H., Kuusela, E., Suvitie, M., Huhtanen, P. 2002. Effect of protein and energy supplements on milk production in organic farming. Anim. Feed Sci.Techn. 98: 103-119.

Kuoppala, K., Ahvenjärvi, S., Rinne, M., Vanhatalo, A. 2006. Puna-apilasäilörehun solunseinäkuitu on erilaista kuin timotei-nurminatasäilörehun. Maataloustieteen päivät 2006.

McDonald, P., Henderson A. R., Heron, S. J. E. 1991. The Biochemistry of Silage. 2nd ed. Chalcombe

Publ. UK, $340 \mathrm{p}$.

Mustonen, E.,Tuori, M., Saastamoinen, I., Nykänen-Kurki, P., Isolahti, M., Saloniemi, H., Vanhatalo A.

2006. Puna-apilalajikkeiden kasviestrogeenit. Maataloustieteen päivät 2006.

Pursiainen, P., Tuori, M., Kuopala, K., Rinne, M., Huhtanen, P., Vanhatalo, A. 2006. Puna-apilasäilörehujen korjuuajan vaikutus maidontuotantoon. Maataloustieteen päivät 2006.

Rinne, M. 2000. Influence of the timing of the harvest of primary grass growth on herbage quality and subsequent digestion and performance in the ruminant animal. Helsingin yliopiston kotieläintieteen laitoksen julkaisuja 54: 42 p. +5 encl. Diss.: Helsinki: Helsingin yliopisto, 2000. (Väitöskirja).

Rinne, M., Kuoppala, K., Ahvenjärvi, S., Vanhatalo, A. 2006. Rypsi soijaa parempi lypsylehmien valkuaistäydennys myös apilapitoista säilörehua syötettäessä. Maataloustieteen päivät 2006.

Scollan, N.D., Dewhurst, R.J., Moloney, A.P., Murphy, J.J. 2005. Improving the quality of products from grassland. In: McGilloway, D.A. (toim). Grassland: a global resource. p. 41-56. 
Sullivan, M.L., Hatfield, R.D., Thoma, S., Samac, D.A. 2004. Cloning of red clover polyphenol oxidase Cdnas and expression of active protein in escherichia coli and transgenic alfalfa. Plant Physiology. 136: 3234-3244.

Syrjälä-Qvist, L., Pekkarinen, E., Setälä, J, Kangasmäki, T. 1984. Effect of red clover/timothy ratio on the protein feeding value and the quality of silage. J. Agric. Sci Finl. 56: 183 - 191.

Syrjälä-Qvist, L., Pekkarinen, E., Kangasmäki, T. 1985. Puna-apilasta ja westerwoldin raiheinästä hyvälaatuista säilörehua. Koetoiminta ja Käytäntö 26.2.1985

Thomas, C., Aston, K., Daley, S.R. 1985. Milk production from silage 3. A comparison of red clover with grass silage. Anim. Prod. 41:23-31.

Tuori, M. , Villikka, U., Huuskonen, A., Syrjälä-Qvist, L. 2000. Puna-apila ja vuohenhernesäilörehut puhtaana sekä nurmisäilörehun kanssa seoksena lypsylehmien ruokinnassa. Maataloustieteen Päivät 2000 Kotieläintiede. Maaseutukeskusten Liiton julkaisuja nro 952 p. 134-137.

Tuori, M., Seppälä, A., Nousiainen, J., Hellämäki, M. , Syrjälä-Qvist, L. 2000. Erilaiset säilöntäaineet nurmipalkokasvien säilönnässä. Maataloustieteen Päivät 2000 Kotieläintiede. Maaseutukeskusten Liiton julkaisuja nro 952 p. 113-117.

Tuori, M., Syrjälä-Qvist, L. \& Jansson, S. 2002. Puna-apila- ja nurminatasäilörehu eri suhteissa lypsylehmien ruokinnassa. In: Rinne, M. (toim.). Maataloustieteen Päivät 2002. Kotieläintiede. Maaseutukeskusten Liiton julkaisuja nro 977. p. 143-146.

Vanhatalo, A., Heikkilä, T., Gäddnäs, T. 1995. Puna-apilapitoinen säilörehu lypsylehmien ruokinnassa: vaikutus valkuaissynteesiin, pötsifermentaatioon ja maidontuotantoon heinäsäilörehuun verrattuna. In: Jokela, M. (toim.). Kotieläintieteen Päivät 1995. Maaseutukeskusten Liiton julkaisuja nro 888. p. 190-193.

Vanhatalo, A., Kuoppala, K., Ahvenjärvi, S., Rinne, M. 2006. Puna-apilasäilörehun vaikutus lypsylehmien ravintoaineiden saantiin. Maataloustieteen päivät 2006.

Wilkins, R.J. 2001. Why forage legumes?. Nurmipalkokasvien tuotanto ja käyttömahdollisuudet. Professori Liisa Syrjälä-Qvistin juhlaseminaari 1.11.2001. p. 10-13.

Van Soest, P. J. 1994. Nutritional ecology of the ruminant. $2^{\text {nd }}$ edition, Cornell University Press, Ithaca, NY, $476 \mathrm{p}$. 